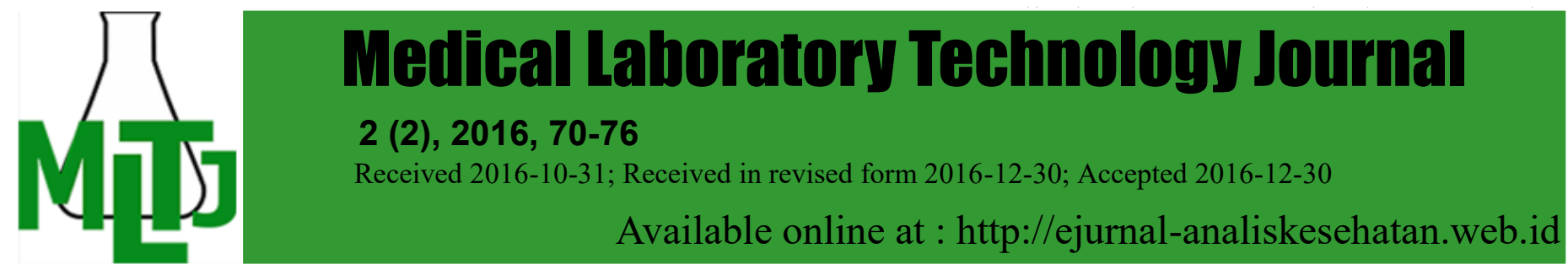

\title{
POTENSI EKSTRAK RIMPANG KENCUR (Kaempferia galanga L.) MENGHAMBAT PERTUMBUHAN Candida albicans
}

\author{
Annisa Rahmi, Erfan Roebiakto, Leka Lutpiatina \\ Jurusan Analis Kesehatan Poltekkes Kemenkes Banjarmasin \\ Jl Mistar Cokrokusumo 4a Banjarbaru \\ e-mail: leka.zns@gmail.com
}

\begin{abstract}
Candida albicans infection is the cause of candidiasis. Candidiasis treatment can be done with a variety of antifungal drugs, one of them is rhizome of kencur (Kaempferia galanga L.). The Rhizome of kencur is selected as a traditional medicine because it contains chemical compounds such as flavonoids, tannins, saponins and essential oil that serves as an antifungal. This study aimed to determine the minimal inhibitory and minimal killing power and also an influence of kencur rhizome extract on the growth of Candida albicans in vitro. This research was true experimental design with posttest only control group design with tube dilution method. Results of Minimal Inhibitory Concentrations (MICs) research showed there was no clarity at concentration of $20 \mathrm{mg} / \mathrm{mL}, 30 \mathrm{mg} / \mathrm{mL}, 40 \mathrm{mg} / \mathrm{mL}$, and it shows clarity at concentration of 50 $\mathrm{mg} / \mathrm{mL}$ and $60 \mathrm{mg} / \mathrm{mL}$. Results of Minimum Bactericidal Concentrations (MBCs) showed the number of colonies at concentration of $20 \mathrm{mg} / \mathrm{mL}$ were 84 colonies, concentration of $30 \mathrm{mg} / \mathrm{mL}$ were 48 colonies, concentration of $40 \mathrm{mg} / \mathrm{mL}$ were 27 colonies, concentration of $\mathrm{mg} / \mathrm{mL}$ were 12 colonies and concentration of $60 \mathrm{mg} / \mathrm{mL}$ were 0 colony. Based on linear regression test, the result showed significance value of $0.000<a=0.05$ so it can be concluded that there is a kencur rhizome extract influence on the growth of Candida albicans in vitro with minimal inhibitory concentrations is the concentration of $50 \mathrm{mg} / \mathrm{mL}$ and the minimal bactericidal concentrations 60 $\mathrm{mg} / \mathrm{mL}$. Further studies are required regarding kencur rhizome extract (Kaempferia galanga L.) in inhibiting and bactericidal microorganisms other than Candida albicans.
\end{abstract}

Keywords: Kencur (Kaempferia galanga L.); Candida albicans

Abstrak: Infeksi Candida albicans merupakan penyebab terjadinya kandidiasis. Perawatan kandidiasis dapat dilakukan dengan berbagai macam obat antijamur, salah satunya rimpang kencur (Kaempferia galanga L.). Rimpang kencur dipilih sebagai obat tradisional karena memiliki kandungan senyawa kimia seperti flavonoid, tanin, saponin dan minyak atsiri yang berfungsi sebagai antijamur. Penelitian ini bertujuan untuk mengetahui daya hambat minimal dan daya bunuh minimal serta pengaruh ekstrak rimpang kencur terhadap pertumbuhan Candida albicans secara in vitro. Penelitian ini bersifat true eksperiment dengan rancangan postest only control group design melalui metode dilusi tabung. Hasil penelitian Konsentrasi Hambat Minimal (KHM) menunjukkan tidak adanya kejernihan pada konsentrasi $20 \mathrm{mg} / \mathrm{ml}, 30 \mathrm{mg} / \mathrm{ml}, 40$ $\mathrm{mg} / \mathrm{ml}$, dan tampak adanya kejernihan pada konsentrasi $50 \mathrm{mg} / \mathrm{ml}$ dan $60 \mathrm{mg} / \mathrm{ml}$. Hasil Konsentrasi Bunuh Minimal (KBM) diperoleh jumlah koloni pada konsentrasi $20 \mathrm{mg} / \mathrm{ml}$ sebanyak $84 \mathrm{koloni}, 30 \mathrm{mg} / \mathrm{ml}$ sebanyak $48 \mathrm{koloni}, 40 \mathrm{mg} / \mathrm{ml}$ sebanyak $27 \mathrm{koloni}, 50 \mathrm{mg} / \mathrm{ml}$ sebanyak 12 koloni dan $60 \mathrm{mg} / \mathrm{ml}$ sebanyak 0 koloni. Berdasarkan uji regresi linier diperoleh nilai signifikasi sebesar 0,000<a=0,05 sehingga dapat disimpulkan bahwa ada pengaruh ekstrak rimpang kencur terhadap pertumbuhan Candida albicans secara in vitro dengan konsentrasi hambat minimal $50 \mathrm{mg} / \mathrm{ml}$ dan konsentrasi bunuh minimal $60 \mathrm{mg} / \mathrm{ml}$. Perlu penelitian lebih lanjut mengenai ekstrak rimpang kencur (Kaempferia galanga L.) dalam menghambat dan membunuh mikroorganisme lain selain Candida albicans.

Kata kunci: Kencur (Kaempferia galanga L.); Candida albicans 


\section{PENDAHULUAN}

Candida albicans adalah salah satu ragi lonjong dan bertunas yang menghasilkan pseudomiselium baik dalam biakan maupun dalam jaringan dan eksudat. Candida albicans merupakan anggota flora normal selaput mukosa saluran pernafasan, pencernaan dan genitalia wanita sehingga sering ditemukan pada beberapa bagian tubuh orang yang sehat, seperti di dalam mulut, kerongkongan, usus, saluran genital, feses, di bawah kuku dan kulit (Jawetz, 1996). Infeksi Candida albicans akan terjadi apabila terdapat faktor predisposisi, termasuk diantaranya pemakaian antibiotik berspektrum luas, diabetes mellitus, pemakaian steroid topikal ataupun sistemik, kehamilan dan sistem pertahanan tubuh yang menurun sehingga menghasilkan lingkungan yang lembab dan menimbulkan kandidiasis (Entjang, 2003).

Kandidiasis adalah suatu infeksi dari spesies Candida albicans yang dapat menyerang berbagai jaringan tubuh seperti rongga mulut dan vagina. Menurut Akpan dan Morgan (2002) pada rongga mulut orang dewasa sehat terdapat sekitar 30-40\% Candida albicans, 65$88 \%$ pada orang yang mengkonsumsi obatobatan spektrum luas dalam jangka panjang dan $90 \%$ pada pasien leukemia akut yang menjalani kemoterapi. Sementara itu menurut Hermilasari dkk. (2012) terdapat sekitar 5-10\% Candida albicans pada vagina dan akan mengalami peningkatan sekitar $40 \%$ pada wanita hamil. Data Departemen Kesehatan RI hingga bulan Maret tahun 2009 menyebutkan bahwa kandidiasis menjadi infeksi penyerta ketiga terbanyak pada penderita HIVIAIDS yaitu sebesar 4897 kasus. Berdasarkan hasil kunjungan peneliti di Rumah Sakit Ratu Zalecha Martapura, pada bulan April sampai Desember 2010 terdapat pasien dengan infeksi kandidiasis pada urin dengan jumlah sebanyak 6 kasus, pada bulan Januari sampai Desember 2011 terdapat 4 kasus dan pada bulan Januari sampai Desember 2012 sebanyak 10 kasus.

Perawatan kandidiasis dapat dilakukan dengan berbagai macam obat antijamur, baik secara kimia maupun tradisional. Menurut Winarto (2007) penggunaan obat tradisional dianggap lebih menguntungkan karena memberikan efek samping yang lebih kecil dibandingkan dengan pengobatan secara kimia, sehingga masyarakat kembali memakai obat-obat alamiah yang berasal dari tumbuhtumbuhan, salah satu diantaranya adalah rimpang kencur.

Rimpang kencur (Kaempferia galanga L.) merupakan tanaman yang bernilai ekonomis cukup tinggi sehingga banyak dibudidayakan dan digunakan sebagai bumbu makanan atau untuk pengobatan salah satunya antijamur (Winarto, 2007). Di wilayah Kalimantan Selatan Masyarakat memanfaatkan rimpang kencur sebagai obat dengan membuat minuman dalam bentuk jamu, menempelkan parutan rimpang kencur pada bagian tubuh yang diobati atau mengkonsumsi secara langsung rimpang kencur tersebut untuk mengobati sariawan (Kuntorini, 2005). Menurut Hermilasari dkk. (2012) kandungan zat aktif berupa flavonoid, tanin, sineol dan saponin dalam rimpang kencur (Kaempferia galanga L.) memiliki sifat antijamur yang dapat memberikan efek sinergis terhadap pertumbuhan jamur salah satunya adalah Candida albicans.

Berdasarkan hasil penelitian Hafidza (2014) menunjukkan bahwa ekstrak rimpang kencur (Kaempferia galanga L.) dapat menghambat pertumbuhan Escherichia coli dengan konsentrasi hambat minimal sebesar $80 \%$. Penelitian Gholib (2009) mengenai daya hambat ekstrak kencur (Kaempferia galanga L.) terhadap Trichophyton mentagrophytes dan Cryptococcus neoformans dengan metode difusi diperoleh hasil bahwa ekstrak kencur (Kaempferia galanga L.) mampu menghambat pertumbuhan Trichophyton mentagrophytes dan Cryptococcus neoformans dengan konsentrasi hambat minimal ekstrak sebesar $0,15 \%$ terhadap Trichophyton mentagrophytes dan $2 \%$ terhadap Cryptococcus neoformans. Selain itu rimpang kencur juga memiliki kemampuan dalam menghambat dan membunuh pertumbuhan Candida albicans. Hasil uji pendahuluan yang dilakukan oleh peneliti didapatkan bahwa ekstrak rimpang kencur (Kaempferia galanga L.) memiliki kemampuan dalam membunuh Candida albicans secara in vitro pada konsentrasi $60 \mathrm{mg} / \mathrm{ml}$. Penelitian ini bertujuan untuk mengetahui daya hambat minimal dan daya bunuh minimal serta pengaruh ekstrak rimpang kencur terhadap pertumbuhan Candida albicans secara in vitro.

\section{BAHAN DAN METODE}

Jenis penelitian yang digunakan dalam penelitian ini adalah eksperimen sebenarnya (true eksperiment) dengan rancangan Postest Only Control Group Design (Notoadmodjo, 2012) 
Pemeriksaan daya hambat dan daya bunuh ekstrak rimpang kencur (Kaempferia galanga L.) pada konsentrasi $20 \mathrm{mg} / \mathrm{ml}, 30$ $\mathrm{mg} / \mathrm{ml}, 40 \mathrm{mg} / \mathrm{ml}, 50 \mathrm{mg} / \mathrm{ml}$ dan $60 \mathrm{mg} / \mathrm{ml}$ dan dibandingkan dengan kelompok kontrol negatif, kontrol positif dan kontrol ekstrak dengan jumlah pengulangan sebanyak 3 kali.

Bahan yang digunakan dalam penelitian ini adalah rimpang kencur yang ada di daerah Banjarmasin dengan kriteria rimpang kencur berusia 5 bulan, utuh dengan berat \pm 10 gram, kulit tidak mengkerut berwarna putih kecoklatan pada bagian luar dan berwarna putih kekuningan di bagian dalam.

Penelitian ini dilaksanakan pada bulan April 2016 dan dilakukan d Laboratorium Bakteriologi Jurusan Analis Kesehatan Politeknik Kesehatan Kementerian Kesehatan Banjarmasin. Variabel bebas dalam penelitian ini konsentrasi ekstrak rimpang kencur (Kaempferia galanga L.) yaitu $20 \mathrm{mg} / \mathrm{ml}, 30 \mathrm{mg} / \mathrm{ml}, 40 \mathrm{mg} /$ $\mathrm{ml}, 50 \mathrm{mg} / \mathrm{ml}$ dan $60 \mathrm{mg} / \mathrm{ml}$. Variabel terikat dalam penelitian ini adalah jumlah koloni Candida albicans pada media sabouraud dextrose agar yang didapat berdasarkan hasil Konsentrasi Bunuh Minimal (KBM).

Pengujian dilakukan dengan cara rimpang kencur dibersihkan dengan air mengalir dan dipotong-potong tipis. Dikeringkan hingga benar-benar kering dengan menggunakan oven pada suhu $60^{\circ} \mathrm{C}$ dan kemudian dihaluskan (simplisia). Ditimbang sebanyak $30 \mathrm{~g}$ rimpang kencur kemudian diekstraksi dengan $150 \mathrm{ml}$ etanol $70 \%$ secara maserasi selama 3 hari sambil sesekali diaduk. Setelah 3 hari, fittrat diambil dan ditampung.

Ampas rimpang kencur dimaserasi kembali dan diulang sebanyak 3 kali dengan 150 $\mathrm{ml}$ etanol $70 \%$ agar dapat dipastikan zat aktif rimpang kencur terekstraksi secara sempurna. Hasil yang diperoleh disaring dengan kertas saring.

Filtrat dipekatkan dengan menguapkan etanol menggunakan waterbath hingga terbentuk ekstrak kental. Ekstrak kental rimpang kencur ditimbang seberat $4 \mathrm{~g}$ dan dilarutkan dengan $4 \mathrm{ml}$ pelarut propilen glikol (konsentrasi $1000 \mathrm{mg} / \mathrm{ml}$ ). Dihomogenkan sampai ekstrak rimpang kencur kental terlarut sempurna. Di dalam tabung steril dimasukkan $2 \mathrm{ml}$ ekstrak rimpang kencur konsentrasi 1000 $\mathrm{mg} / \mathrm{ml}$ ditambah $8 \mathrm{ml}$ TSB steril sehingga diperoleh konsentrasi $200 \mathrm{mg} / \mathrm{ml}$.

Membuat deret konsentrasi ekstrak rimpang kencur pada masing masing tabung reaksi steril seperti pada tabel berikut:
Tabel 1. Pengenceran konsentrasi

\begin{tabular}{cccc}
$\begin{array}{c}\text { Tabung } \\
\text { steril }\end{array}$ & $\begin{array}{c}\text { Larutan } \\
200 \mathrm{mg} / \mathrm{ml}\end{array}$ & TSB & $\begin{array}{c}\text { Konsentrasi } \\
\mathrm{mg} / \mathrm{ml}\end{array}$ \\
\hline 1 & $0.6 \mathrm{ml}$ & $1.4 \mathrm{ml}$ & 60 \\
2 & $0.5 \mathrm{ml}$ & $1.5 \mathrm{ml}$ & 50 \\
3 & $0.4 \mathrm{ml}$ & $1.6 \mathrm{ml}$ & 40 \\
4 & $0.3 \mathrm{ml}$ & $1.7 \mathrm{ml}$ & 30 \\
5 & $0.2 \mathrm{ml}$ & $1.8 \mathrm{ml}$ & 20 \\
\hline
\end{tabular}

Penentuan Konsentrasi Hambat Minimal (KHM). Konsentrasi $60 \mathrm{mg} / \mathrm{ml}=$ diambil $1 \mathrm{ml}$ dari tabung konsentrasi $60 \mathrm{mg} / \mathrm{ml}$ ekstrak rimpang kencur dan ditambah $1 \mathrm{ml}$ suspensi jamur Candida albicans yang tumbuh di dalam kaldu umur 4 jam pada suhu $37^{\circ} \mathrm{C}$. Lakukan pengulangan sebanyak 3 kali. Hal yang serupa dilakukan untuk konsentrasi lain. Tabung kontrol positif diisi dengan suspensi antijamur ketokonazol $200 \mathrm{mg}$ dan TSB steril sebanyak $1 \mathrm{ml}$ kemudian ditambah dengan 1 $\mathrm{ml}$ suspensi jamur Candida albicans yang tumbuh di dalam kaldu umur 4 jam pada suhu $37^{\circ} \mathrm{C}$. Lakukan pengulangan sebanyak 3 kali. Tabung kontrol negatif diisi dengan $1 \mathrm{ml}$ TSB steril ditambah $1 \mathrm{ml}$ suspensi jamur Candida albicans yang tumbuh di dalam kaldu umur 4 jam pada suhu $37^{\circ} \mathrm{C}$. Lakukan pengulangan sebanyak 3 kali. Tabung kontrol ekstrak kencur diisi dengan $1 \mathrm{ml}$ ekstrak rimpang kencur ditambah $1 \mathrm{ml}$ TSB steril. Lakukan pengulangan sebanyak 3 kali. Dicampur baik-baik dan diinkubasi selama 24 jam pada suhu $37^{\circ} \mathrm{C}$ di dalam inkubator. Dibaca hasilnya dengan mencari tabung yang mengandung kadar ekstrak terendah tetapi masih mampu menghambat Candida albicans (larutan jernih) yang dinyatakan sebagai Konsentrasi Hambat Minimal (KHM).

Penentuan Konsentrasi Bunuh Minimal (KBM). Tabung yang telah diinkubasi selama 24 jam pada suhu $37^{\circ} \mathrm{C}$ dan diamati adanya kekeruhan untuk melihat KHM kemudian dilakukan penamaman pada media sabauroud dextrose agar (SDA) untuk melihat Konsentrasi Bunuh Minimal (KBM). Sebanyak 5 ul larutan diambil dari masing-masing konsentrasi kemudian diratakan pada permukaan media Sabauroud Dextrose Agar (SDA) dengan menggunakan batang penyebar. Diinkubasi selama 24 jam pada suhu $37^{\circ} \mathrm{C}$ di dalam inkubator. Dibaca hasil dengan menghitung jumlah koloni yang tumbuh pada permukaan media kemudian dicari konsentrasi yang sama sekali tidak menunjukkan pertumbuhan koloni jamur Candida albicans. 


\section{HASIL DAN PEMBAHASAN}

Pengujian antimikroba ekstrak rimpang kencur terhadap pertumbuhan Candida albicans memperlihatkan adanya tingkat kejernihan pada penentuan Konsentrasi Hambat Minimal (KHM).

Tabel 2 Hasil Konsentrasi Hambat Minimal (KHM) Ekstrak Rimpang Kencur terhadap Pertumbuhan Candida albicans

\begin{tabular}{lllll}
\hline \multirow{2}{*}{$\begin{array}{c}\text { Konsentrasi } \\
\text { ekstrak }\end{array}$} & \multicolumn{3}{c}{ Tingkat kejernihan } & $\begin{array}{c}\text { Rata- } \\
\text { rata }\end{array}$ \\
\cline { 2 - 5 } rimpang kencur & I & II & III & \\
\hline $20 \mathrm{mg} / \mathrm{ml}$ & Keruh & Keruh & Keruh & Keruh \\
$30 \mathrm{mg} / \mathrm{ml}$ & Keruh & Keruh & Keruh & Keruh \\
$40 \mathrm{mg} / \mathrm{ml}$ & Keruh & Keruh & Keruh & Keruh \\
$50 \mathrm{mg} / \mathrm{ml}$ & Jernih & Jernih & Jernih & Jernih \\
$60 \mathrm{mg} / \mathrm{ml}$ & Jernih & Jernih & Jernih & Jernih \\
$\mathrm{K}(+)$ & Jernih & Jernih & Jernih & Jernih \\
$\mathrm{K}(-)$ & Keruh & Keruh & Keruh & Keruh \\
Kontrol Kencur & Jernih & Jernih & Jernih & Jernih
\end{tabular}

Berdasarkan penentuan Konsentrasi Bunuh Minimal (KBM) diperoleh adanya pertumbuhan jumlah koloni terbesar terjadi pada konsentrasi $20 \mathrm{mg} / \mathrm{ml}$ dengan jumlah koloni sebanyak 84 koloni dan pertumbuhan koloni terkecil terjadi pada konsentrasi $60 \mathrm{mg} / \mathrm{ml}$ dengan jumlah koloni sebanyak 0 koloni.

Tabel 3. Hasil Konsentrasi Bunuh Minimal (KBM) Ekstrak Rimpang Kencur terhadap Pertumbuhan Candida albicans

\begin{tabular}{|c|c|c|c|c|}
\hline \multirow{2}{*}{$\begin{array}{l}\text { Konsentrasi } \\
\text { ekstrak } \\
\text { rimpang kencur }\end{array}$} & \multicolumn{3}{|c|}{ Jumlah koloni } & \multirow{2}{*}{$\begin{array}{l}\text { Rata- } \\
\text { rata }\end{array}$} \\
\hline & I & II & III & \\
\hline $20 \mathrm{mg} / \mathrm{ml}$ & 95 & 83 & 74 & 84 \\
\hline $30 \mathrm{mg} / \mathrm{ml}$ & 47 & 44 & 53 & 48 \\
\hline $40 \mathrm{mg} / \mathrm{ml}$ & 24 & 27 & 29 & 27 \\
\hline $50 \mathrm{mg} / \mathrm{ml}$ & 13 & 12 & 11 & 12 \\
\hline $60 \mathrm{mg} / \mathrm{ml}$ & 0 & 0 & 0 & 0 \\
\hline $\mathrm{K}(+)$ & 0 & 0 & 0 & 0 \\
\hline $\mathrm{K}(-)$ & 4544 & 5008 & 2336 & 3963 \\
\hline Kontrol Kencur & 0 & 0 & 0 & \\
\hline
\end{tabular}

Hasil rata-rata jumlah koloni Candida albicans tiap konsentrasi pada penentuan konsentrasi bunuh minimal disajikan seperti pada gambar.

Gambar1. Grafik Rata-rata Jumlah Koloni Candida Albicans Berbagai Konsentrasi pada Penentuan Konsentrasi Bunuh Minimal (KBM)

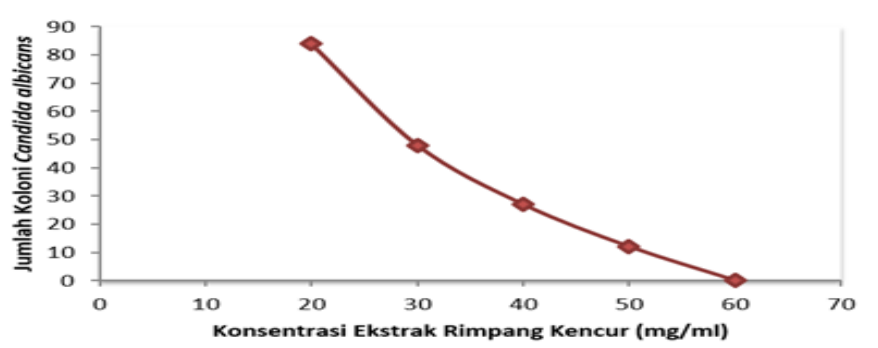

Berdasarkan hasil konsentrasi bunuh minimal diperoleh adanya penurunan jumlah koloni pada pemberian berbagai konsentrasi ekstrak rimpang kencur sehingga dilakukan uji normalitas data untuk mengetahui data yang digunakan berdistribusi normal atau tidak karena syarat uji regresi yaitu data harus berdistribusi normal. Berdasarkan hasil uji normalitas data dengan menggunakan Shapiro-Wilk, diketahui nilai asymp. Sig $=0,119$. Apabila nilai asymp. Sig > 0,05 maka dapat dinyatakan bahwa data konsentrasi Bunuh Minimal (KBM) berdistribusi normal.

Pengujian dilanjutkan dengan uji Anova untuk menilai kualitas persamaan regresi yang diperoleh. Suatu persamaan dinyatakan layak untuk digunakan apabila nilai signifikasi pada uji Anova $<0,05$. Berdasarkan hasil uji Anova diperoleh nilai signifikasi 0,000 sehingga persamaan yang didapat layak untuk digunakan.

Pengujian dilanjutkan ke uji Regresi untuk mengetahui pengaruh ekstrak rimpang kencur terhadap pertumbuhan Candida albicans. Berdasarkan hasil uji regresi didapatkan nilai signifikasi 0,000 . Apabila nilai signifikasi $<a=0,05$ maka dapat dinyatakan bahwa perlakuan konsentrasi yang berbeda dari ekstrak rimpang kencur berpengaruh terhadap pertumbuhan Candida albicans secara in vitro dengan persamaan garis regresi $y=95,33-$ 20,4x ( $x=$ konsentrasi, $y=$ jumlah koloni Candida albicans).

Untuk melihat seberapa besar pengaruh konsentrasi ekstrak rimpang kencur tehadap pertumbuhan Candida albicans dilakukan analisis koefisien determinasi atau disimbolkan dengan $R^{2}$. Berdasarkan hasil uji koefisien determinasi didapatkan nilai $R$ square sebesar 0,928. Nilai ini menyimpulkan bahwa pengaruh ekstrak rimpang kencur terhadap pertumbuhan Candida albicans sebesar $92,8 \%$ (didapat dari $0,928 \times 100 \%$ ), yang berarti ekstrak rimpang kencur memiliki pengaruh yang kuat terhadap pertumbuhan Candida albicans.

Kencur (Kaempferia galanga L.) merupakan satu di antara tanaman suku Zingiberaceae yang telah dikaji dan dimanfaatkan sebagai fungisida alami. Akar rimpang kencur adalah bagian yang digunakan sebagai obat. Menurut Winarto (2007) komponen yang terkandung di dalam rimpang kencur seperti saponin, flavonoid, polifenol dan minyak atsiri memiliki manfaat untuk pengobatan seperti batuk, mual, bengkak, bisul, antitoksin dan antijamur. 
Penelitian ini dilakukan untuk mengetahui pengaruh ekstrak rimpang kencur (Kaempferia galanga L.) terhadap pertumbuhan Candida albicans secara in vitro. Rimpang kencur yang telah dibersihkan dan diiris tipis terlebih dahulu dibuat menjadi simplisia. Tujuan pembuatan simpilisia ini yaitu untuk menurunkan kadar air pada rimpang, biasanya tidak lebih dari $8 \%$. Kadar air yang rendah diharapkan dapat menghambat pertumbuhan kapang dan reaksi kimia yang diperantarai oleh air, seperti reaksi redoks atau reaksi enzimatis. Selain itu pada kadar air lebih dari $8 \%$ enzim mulai mendegradasi bahan aktif yang terkandung pada tanaman (Kumoro, 2015). Simplisia yang telah dibuat kemudian diekstrak secara maserasi dengan menggunakan pelarut etanol $70 \%$ dan dilanjutkan dengan penentuan konsentrasi hambat minimal dan konsentrasi bunuh minimal. Penentuan Konsentrasi Hambat Minimal (KHM) dengan menggunakan uji dilusi tabung menunjukkan adanya kekeruhan pada konsentrasi $20 \mathrm{mg} / \mathrm{ml}, 30 \mathrm{mg} / \mathrm{ml}$ dan $40 \mathrm{mg} / \mathrm{ml}$. Hal ini terjadi karena masih adanya pertumbuhan Candida albicans pada konsentrasi tersebut, namun pada konsentrasi $50 \mathrm{mg} / \mathrm{ml}$ dan $60 \mathrm{mg} / \mathrm{ml}$ tampak adanya kejernihan pada media, yang berarti pada konsentrasi tersebut pertumbuhan Candida albicans sudah terhambat sehingga Konsentrasi Hambat Minimal (KHM) terjadi pada konsentrasi $50 \mathrm{mg} / \mathrm{ml}$.

Penelitian Hermilasari dkk. (2012) tentang Efektivitas Ekstrak Etanol Rimpang Kencur (Kaempferia galanga L.) dalam Menghambat Pertumbuhan Candida albicans Isolat 218 -Sv secara In Vitro diperoleh Konsentrasi Hambat Minimal (KHM) dari ekstrak etanol rimpang kencur (Kaempferia galanga L.) adalah pada konsentrasi 4\%. Penelitian lainnya yaitu Tarmizi dan Binti (2012) tentang Efektivitas Konsentrasi Infusa Rimpang Kencur Kaempferia galanga L.) terhadap Pertumbuhan Koloni Candida albicans diperoleh Konsentrasi Hambat Minimal (KHM) pada konsentrasi $30 \%$. Adanya perbedaan hasil penelitian antara peneliti dengan peneliti lain ini dapat disebabkan oleh perbedaan proses ekstraksi dan teknik ekstraksi yang dilakukan yang mana pada penelitian Hermilasari dkk. (2012) pada proses ekstraksi menggunakan evaporator untuk menguapkan ekstrak yang telah dimaserasi sedangkan peneliti hanya menguapkan di udara terbuka sehingga menyebabkan zat aktif yang dapat menguap diperoleh kurang maksimal. Sementara itu penelitian Tarmizi dan Binti (2012) menggunakan teknik ekstraksi berbeda dengan teknik ekstraksi yang dilakukan oleh peneliti, yang mana penelitian Tarmizi dan Binti (2012) menggunakan teknik ekstraksi infusa sedangkan peneliti menggunakan teknik ekstraksi maserasi dengan pelarut etanol $70 \%$. Teknik ekstraksi maserasi menggunakan pelarut etanol $70 \%$ dianggap lebih baik karena bersifat semipolar dan sangat efektif dalam menghasilkan jumlah bahan aktif yang optimal dalam rimpang kencur terutama senyawa fenol seperti flavonoid dan tanin dibandingkan dengan teknik infusa yang harus mempertimbangkan ketahanan senyawa zat aktif yang diekstraksi terhadap paparan dingin atau panas karena teknik ekstraksi infusa merupakan teknik ekstraksi bagian tanaman dengan menggunakan air dingin atau air mendidih (Kumoro, 2015). Selanjutnya Haniah (2008) menyebutkan bahwa terdapat beberapa faktor yang dapat mempengaruhi kerja zat antimikroba. Faktorfaktor tersebut diantaranya adalah umur tanaman yaitu paling baik berusia 5-6 bulan, keadaan mikroba, suhu lingkungan dan kandungan zat aktif antimikroba tanaman, yang mana semakin besar kandungan zat aktif antimikroba suatu tanaman maka semakin besar pula kemampuannya dalam menghambat pertumbuhan mikroorganisme.

Selain memiliki kemampuan dalam menghambat pertumbuhan Candida albicans, rimpang kencur juga memiliki kemampuan dalam membunuh Candida albicans yang dapat dilihat berdasarkan penentuan Konsentrasi Bunuh Minimal (KBM). Setelah mengamati tingkat kejernihan untuk melihat Konsentrasi Hambat Minimal (KHM), tiap-tiap konsentrasi larutan ekstrak rimpang kencur ditanam pada media sabouroud dextrose agar untuk melihat Konsentrasi Bunuh Minimal (KBM). Berdasarkan hasil pertumbuhan dan perhitungan jumlah koloni yang tumbuh pada permukaan media sabouroud dextrose agar dapat ditentukan bahwa Konsentrasi Bunuh Minimal (KBM) terjadi pada konsentrasi $60 \mathrm{mg} / \mathrm{ml}$ dimana pada konsentrasi tersebut tidak ditemukan adanya pertumbuhan koloni Candida albicans.

Hasil penelitian menunjukkan bahwa semakin tinggi tingkat konsentrasi ekstrak rimpang kencur yang ditambahkan, semakin besar pula kemampuan daya hambat dan daya bunuh ekstrak rimpang kencur terhadap pertumbuhan Candida albicans. Hal ini ditandai dengan terjadinya kejernihan pada media TSB uji dilusi tabung dan penurunan jumlah koloni Candida albicans yang tumbuh pada permukaan media sabouroud dextrose agar. 
Berdasarkan hasil uji regresi diperoleh nilai signifikasi $0,000<a=0,05$ sehingga ada pengaruh pemberian konsentrasi ekstrak rimpang kencur terhadap pertumbuhan Candida albicans. Hal ini terjadi karena adanya bahan aktif yang bersifat sebagai antijamur yang terkandung dalam rimpang kencur. Menurut Hermilasari dkk. (2012) bahan aktif yang terkandung dalam rimpang kencur yang bersifat sebagai antijamur adalah flavonoid, tanin dan saponin. Flavonoid dalam rimpang kencur bekerja dalam penghambat sintesis asam nukleat jamur yang mengakibatkan tidak terjadinya proses pembentukan DNA dan RNA pada sel jamur. Sedangkan menurut Robinson (1995) Flavonoid mempunyai respon terhadap infeksi jamur dengan mekanisme kerja menghancurkan protein dan menyebabkan lisis pada membran sel mikroorganisme yang bersifat irreversible.

Menurut Sumono dan Wulan (2008) tanin dalam rimpang kencur bekerja menghambat pertumbuhan jamur dengan presipitasi dan denaturasi protein jamur. Tanin memiliki sasaran terhadap polipeptida dinding sel yang menyebabkan kerusakan pada dinding sel jamur. Kerusakan dan peningkatan permeabilitas sel jamur menyebabkan pertumbuhan sel terhambat dan akhirnya menyebabkan kematian sel.

Menurut Rachmawati (2009) mekanisme saponin sebagai antijamur adalah bereaksi dengan porin (protein transmembran) pada membran luar dinding sel jamur dengan cara membentuk ikatan polimer yang kuat sehingga mengakibatkan rusaknya porin yang merupakan pintu keluar masuknya senyawa sehingga akan mengurangi permeabilitas membran sel jamur yang akan mengakibatkan sel jamur kekurangan nutrisi kemudian pertumbuhan jamur terhambat atau mati.

Menurut Hasanah dkk. (2011) zat aktif lain yang terkandung dalam rimpang kencur adalah minyak atsiri. Sumono dan Wulan (2008) menyebutkan bahwa minyak atsiri dalam rimpang kencur memiliki kemampuan untuk menghambat pertumbuhan jamur melalui proses denaturasi protein yang melibatkan perubahan dalam stabilitas molekul protein sehingga menyebabkan perubahan struktur protein dan terjadi proses koagulasi. Protein yang mengalami proses denaturasi akan kehilangan aktifitas fisiologi dan dinding sel akan meningkatkan permeabilitas sel sehingga akan terjadi kerusakan. kencur (Kaempferia galanga L.) terhadap Candida albicans terjadi pada konsentrasi 50 $\mathrm{mg} / \mathrm{ml}$. Daya bunuh minimal ekstrak rimpang kencur (Kaempferia galanga L.) terhadap Candida albicans terjadi pada konsentrasi 60 $\mathrm{mg} / \mathrm{ml}$. Ada pengaruh pemberian konsentrasi ekstrak rimpang kencur (Kaempferia galanga L.) terhadap pertumbuhan Candida albicans secara in vitro sebesar $92,8 \%$ dengan nilai signifikasi 0,000 .

\section{SARAN}

Perlu penelitian lebih lanjut mengenai ekstrak rimpang kencur (Kaempferia galanga L.) dalam menghambat dan membunuh mikroorganisme lain selain Candida albicans.

\section{DAFTAR PUSTAKA}

Entjang I. (2003). Mikrobiologi dan Parasitologi. Citra Aditya Bakti, Bandung.

Gholib, D. (2009). Daya Hambat Ekstrak Kencur (Kaempferia galangal L.) terhadap Trichophyton mentagrophytes dan Cryptococcus neoformans Jamur Penyebab Penyakit Kurap pada Kulit dan Penyakit Paru.

Hafidza, M. (2014). Daya Hambat Ekstrak Rimpang Kencur (Kaempferia galanga L.) terhadap Pertumbuhan Bakteri Escherichia coli. Jurnal Penelitian Fakultas Matematika dan IImu Pengetahuan Alam. Universitas Syiah Kuala Banda Aceh.

Haniah. (2008). Isolasi Jamur Endofit dari Daun Sirih (Piper betle L.) sebagai Antimikroba terhadap Escherichia coli, Staphylococcus aureus, dan Candida albicans. Jurnal Penelitian Universitas Islam Negeri Malang.

Hasanah, A. N., Nazaruddin, F., Febrina, E., \& Zuhrotun, A. (2011). Analisis Kandungan Minyak Atsiri dan Uji Aktivitas Antiinflamasi Ekstrak Rimpang Kencur (Kaempferia galanga L.). Jurnal Matematika Dan Sains Fakultas Farmasi Universitas Padjajaran Bandung, 16(3).

Hermilasari RD, Winarsih S, R. A. (2012). Efektivitas Ekstrak Etanol Rimpang Kencur (Kaempferia galanga Linn) dalam Menghambat Pertumbuhan Candida albicans Isolat 218-SV secara In Vitro. Majalah Fakultas Kedokteran Universitas Brawijaya.

Kumoro, A. (2015). Teknologi Ekstraksi Senyawa Bahan Aktif dari Tanaman Obat. Yogyakarta: Plantaxia.

\section{KESIMPULAN}

Daya hambat minimal ekstrak rimpang 
Kuntorini, E. M. (2005). Botani Ekonomi Suku Zingiberaceae sebagai Obat Tradisional oleh Masyarakat di Kotamadya Banjarbaru. Bioscientiae, 2(1).

Rachmawati, F., Nuria, M. C., \& Sumantri. (2009). Uji Aktivitas Antibakteri Fraksi Kloroform Ekstrak Etanol Pegagan (Centelle asiatica (L) Urb) serta Identifikasi Senyawa Aktifnya. Universitas Wahid Hasyim Semarang.

Robinson, T. (1995). Kandungan Organik Tumbuhan Tinggi. Bandung: In $\mathrm{K}$. Padmawinata ITB.

Sumono, A., \& Wulan, A. (2008). The Use of Bay Leaf (Eugenia Polyantha Wight) in Dentistry. Dental Jurnal. Dental Jurnal, 41.

Tarmizi, \& Binti, S. A. (2012). Efektivitas Konsentrasi Infusa Rimpang Kencur (Kaempferia galanga L.) terhadap Koloni Candida albicans. Universitas Airlangga.

Winarto, W. P. (2007). Tanaman Obat Indonesia Untuk Pengobatan Herbal. Jakarta: Karyasari Herba Media. 